\title{
The Oceanography Classroom Catering to the Multitudes
}

BY MATTHIAS TOMCZAK

Tom Garrison's education column in the last issue of our magazine gave a vivid description of the challenges today's oceanography educators face in a firstyear lecture theatre. In my student days, an introductory course in oceanography was the first step on the way towards a professional career in oceanography, and the class was correspondingly small. Today, a teacher of first-year introductory oceanography faces a class of several hundred students, and teaching oceanography turns into a course of basic science concepts, using examples from the ography $^{1}$ to the principles of mechanics, from statistics to evolution ${ }^{2}$.

In this issue I want to concentrate on second-year teaching, when future professional marine scientists can expect professional training. In the past, such second-year students had received a solid knowledge of the basic science tools during their first year. The profound change of first-year teaching from introductory professional instruction to general science education means that this is no longer true for all students. As a result, the background knowledge of

\section{...the background knowledge of a second-year class varies considerably, and the lecturer has to find ways to satisfy quite different expectations.}

ocean. This generates new challenges for the teacher, who has to correct misconceptions in many fields, from simple ge- a second-year class varies considerably, and the lecturer has to find ways to satisfy quite different expectations.
Changes in government policy have been influential as well. Today's universities are under intense scrutiny by education departments, which often apply simplistic economic measures to university courses. Classes with fewer than 50 students are frowned upon because they represent an "uneconomic" use of a lecturer. As a result, second-year courses originally designed for professional instruction are filled with students of other disciplines to boost class sizes, and course content is adjusted to the new clientele.

In today's global economy, education is becoming more international as well, and universities compete fiercely for the overseas student dollar. The presence of students that went through very different educational systems introduces an additional challenge. To illustrate the range

Matthias Tomczak (matthias.tomczak@ flinders.edu.au) is Professor of Oceanography, Flinders University, Adelaide, Australia.

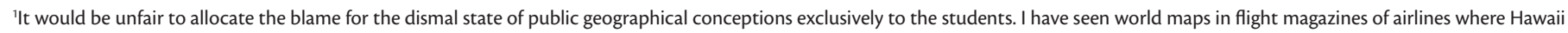
was located halfway between Panama and New Zealand, presumably to provide a convenient layout for the airline's magazine. Another "world map" showed the world minus Africa, since the airline did not fly there. If you want to raise your students' sense of geography, ask a number of airlines to send you a copy of their route network map and discuss what you see with your students!

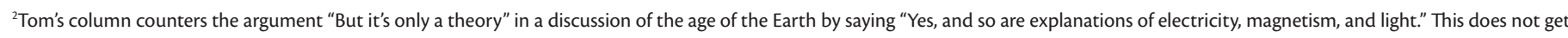

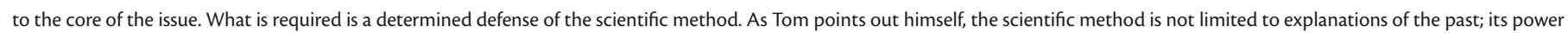
lies in its ability to make predictions. The Academy of Sciences hit the right note when it said: "If petroleum geologists could find more oil and gas by interpreting the record of sedimentary rocks as having resulted from a single flood, they would certainly favor the idea of such a flood, but they do not" (National Academy of Sciences, 1999).
} 
of educational approaches, Box 1 gives examples of student backgrounds from my second-year class.

The problems just described exist in all marine science disciplines. They are particularly serious in physical oceanography, which requires a good base in physics and mathematics. My secondyear course is about the physical dynamics of the large-scale oceanic circulation and its role in climate stability and climate change, so I have to talk about geostrophy, the Ekman layer, the Sverdrup regime, Rossby waves, and similar things. Of the 70 students in my class, fewer than 15 aim to become professional oceanographers or meteorologists, thus most do not bring an adequate level of mathematical knowledge to the class.

How do you present dynamical oceanography without mathematics? How do you talk about Rossby waves without boring students $C, G$, and $H$ and not driving away students $A$ or $D$ ? As in first year, the focus has to be on scientific principles. Given the diversity of students, I try to place it in a global cultural context. I begin with Ockham's razor $^{3}$ : Reduce the problem to the simplest possible situation that still contains the physics of interest. Tides are a good example. An Earth without continents, covered by an ocean of uniform depth, leads to Bernoulli's equilibrium tide of
1740 that explains all tidal periods, the daily inequality, spring and neap tides, and much more. Add continents and you arrive at Laplace's dynamic theory of 1775, which explains phases and amplitudes. Introduce topography and you can explain co-oscillation tides... While talking about $18^{\text {th }}$ century science, you can add cultural diversity and mention what Chinese monks knew about tides 600 years before Bernoulli and Laplace ${ }^{4}$.

My course is not about tides, rather it's about oceanic circulation, but the steps
This alternating exposure to qualitative discussion of general science and quantitative mathematical rigor takes the students on a road of increased understanding that includes patches of boredom for some and patches of total loss for others. Hopefully it impresses on all students the value and importance of mathematics, a branch of science usually held in low regard, and creates in those aiming at professional oceanography the desire to get to the full derivation of the equations in year three.

\section{It does not bother me to hear them say: \\ "That was a hard semester" as long as they add: "But it was definitely worth the effort."}

are the same. I begin with an ocean-covered Earth, introduce rotation, stratification, add continents, and discuss the balance of forces at every step. But that is only half the story. Balances of forces are expressed in equations, so every step, from the simplest to the more complicated, is accompanied by its mathematical form. This cannot include a full derivation of the equations, but it emphasizes that physical oceanography is a quantitative science and that understanding ocean physics requires quantification.
It is a delicate balancing act, but in my experience, the students appreciate it in the end. It does not bother me to hear them say: "That was a hard semester" as long as they add: "But it was definitely worth the effort." 可

\section{REFERENCES}

National Academy of Sciences. 1999. Science and Creationism. National Academy Press, Washington, D.C., USA.

Nai'an, S. and L. Guanzhong. 1980. Outlaws of the Marsh. Foreign Languages Press, Beijing. Chapter 99 translated by Sidney Shapiro.

\footnotetext{
${ }^{3}$ Ockham's razor, named after the Franciscan monk, theologian, philosopher, and political writer William of Ockham (c. 1287-1349), states that, "Plurality should not be posited without necessity" (Pluralitas non est ponenda sine neccesitate). It is often quoted as "Entities should not be multiplied beyond necessity" (Entia non sunt multiplicanda praeter necessitatem), a version not found in Ockham's original text. It embodies a central principle of the scientific method and is also variously known as the "law of parsimony," the "principle of simplicity" and the "KISS principle" (keep it simple, stupid).

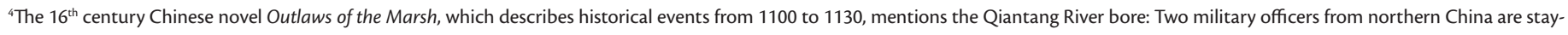

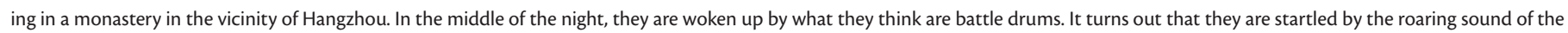

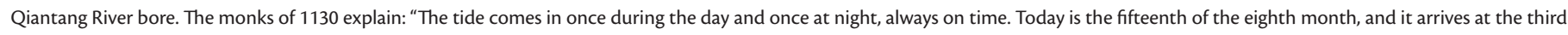
watch. We call it Old Faithful because it's never late" ( Shi Nai'an and Luo Guanzhong, 1980).
} 


\title{
BOX 1: EXAMPLE STUDENT BACKGROUNDS IN A SECOND-YEAR COURSE ON OCEAN DYNAMICS
}

\begin{abstract}
THE EXAMPLES SPEAK FOR THEMSELVES. A tempting general observation could be the comparable importance of religious studies in Indonesia and the United States, while students in Sweden seem to take a more secular approach to world problems - but drawing general conclusions from a sample of eight students is obviously not justifiable. In the context of physical oceanography, the most important point to note is the extreme variation in mathematical knowledge.
\end{abstract}

\section{STUDENT A}

U.K., B.Sc. (Honours), Diploma in Area Studies

- Introductory Microbiology

- Biodiversity

- Earth Surface Processes

- Ecological Processes

- Principles and Practice of Env. Science

- Introduction to Marine Systems

- Atmospheric and Oceanic Systems

- Introductory Coastal Processes

- Marine and Freshwater Chemistry

- Environmental Chemistry

- Marine Biology I

- Marine Mapping and Survey Techniques I

- Aquaculture and Fisheries

\section{STUDENT B}

U.K., B.Sc. (Honours) Physical Geography

- Communications

- Data Collection and Analysis

- Earth Surface Environments

- Earth Systems

- Geographic Information: A Primer

- Principles of Environmental Science

- Spatial Data Applications

\section{STUDENT C}

USA, Undergraduate non-specified

- General Chemistry I*

- General Chemistry II*

- General Biology I*

- General Biology II*

- Physical Geology

- Marine Biology*

- Chemical Oceanography*

- Geol., Chem. and Phys. Oceanography*

- Mineralogy

- Geological Oceanography*

- Oceanographic Field Techniques

- Fieldwork Safety Techniques

- Intro. to Computer Information Systems

- Writing and Critical Analysis

- Introduction to Literature

- Argument, Research and Writing

- Introduction to Theater

- World Civilizations I

- World Civilizations II

- Pre-Calculus I

- Pre-Calculus II

- Calculus I

- Calculus II

- Calculus III

- General Physics I*

- General Physics II*

\section{STUDENT D}

USA, B.Sc. with major in Biology

- Issues in Environmental Biology

- Principles of Chemistry*

- Animal Physiology

- Ecology

- Calculus I

- Molecules, Genes and Cells*

- Organisms, Evolution, Ecosystems*

- Physics of the Environment

- Microanatomy of Vertebrates*

- India

- History of Europe Since 1815

- History of the United States Since 1877

- Introduction to Theology

- Introduction to American Politics

- Introduction to Theatre Arts

- Elementary Spanish I

- Elementary Spanish II

- Contemporary Political Ideologies

- Religion in the Movies

- Intermediate Spanish 


\section{STUDENT E}

Sweden, Magister of Science

- Basic Earth Sciences

- Introductory Mathematics

- $\mathrm{C}++$ programming

- Numerical Computer Calculations

- Mathematics: Multivariable Analysis

- Experimentation and Elementary Mechanics

- Oceanography: Introductory Level (Introduction to Oceanography, Marine Environment, Coastal Oceanography, Case Studies)

- Oceanography: Intermediate Level (Geophysical Fluid Dynamics, Ocean Circulation, Mathematics in the Earth Sciences, Field Course)

- Visualize our Vision of the World

- Mathematics: Single Variable Analysis

\section{STUDENT F}

Sweden, Magister of Science

- Earth Sciences: Basic Course (General Geology**, Oceanography and Climatology**, General Geology Excursion)

- Earth Sciences II: Basic Course (General Geology and Geomorphology**, Historical Geology and Geomorphology**, Meteorology, Glaciology, Hydrogeology**)

- Env. Earth Science Theory and Seminars

- Methods in Earth Science

- Oceanography: Introductory Level (Introduction to Oceanography, Marine Environment, Coastal Oceanography, Case Studies)

- Oceanography: Intermediate Level (Geophysical Fluid Dynamics, Ocean Circulation, Mathematics in the Earth Sciences, Field Course)

- International Relations: Introductory Level (The Emergence of the Modern World System, War, Peace and Security, The World Economic System: Problems of Development and Underdevelopment, Global Problems of Environment and Survival)

\section{STUDENT G}

Indonesia, Magister of Science

- Principles of Physical Oceanography

- Advanced Chemical Oceanography

- Advanced Marine Biology

- Statistical Analysis

- Research Methodology

- Geophysical Fluid Dynamics

- Sea Water Circulations

- Partial Differential Equations

- Colloquium

- Design in Physical Oceanography Processing

- Beach and Estuary Dynamics

- English

- Seminar

\section{STUDENT H}

Indonesia, B.Sc. with major in Oceanography

- Introduction to Computers

- Basic Physics I

- Basic Physics II

- Basic Chemistry I

- Basic Chemistry II

- Calculus I

- Calculus II

- Environmental Impact Analysis

- Environmental Studies

- Principles of Stratigraphy

- Meteorology

- Solid-Earth Geophysics

- Climatology

- Chemical Oceanography

- Oceanography

- Physical Geology I
- Physical Meteorology

- Thermodynamics

- Remote Sensing

- Wave Theory

- Modern Physics

- Computational Physics

- Mathematical Physics I

- Elementary Statistics I

- Numerical Modelling in Fluid Dynamics

- Numerical Analysis

- Advanced Mechanics

- Mechanics

- Concepts of Technology

- Indonesian

- English

- Koran
- Guidance Studies

- Muslim Religion

- Pancasilea ***

- Muslim Ethics

- Hydrodynamics of Atmosphere and Ocean

- Earthquake Seismology

- Ocean Tides

- Ocean Currents

- Ocean Waves

- Coastal Hydraulics

- Oceanography of Indonesia

- Instrumentation

- Advanced Ocean Laboratory

- Modelling the Marine Environment

- Coastal Oceanography 